\title{
FRITZ HABER: HÉROI E VILÃO OU AS DUAS FACES DA CIÊNCIA
}

\author{
Paulo J. Mendes \\ Departamento de Química, Escola de Ciências e Tecnologia, Centro de Química de Évora, Instituto de Investigação e Formação Avançada, \\ Universidade de Évora \\ pjgm@uevora.pt
}

\begin{abstract}
Fritz Haber: Hero and Villain or the Two Faces of Science - The industrial process of ammonia synthesis, which began about 100 years ago, has become an essential pillar of life on the planet due to its importance in the production of fertilizers. However, it was also supported the war machine, making it a form of life destruction. Connecting these two realities is an event - World War I - where scientific communities found themselves intertwined in the promotion and development of new weapons, and a leader - Fritz Haber - a scientist-warrior, whose $80^{\text {th }}$ anniversary of his death is renowned this year. There has never been such a close connection between science and the military, and which were so clearly exposed the two faces of science. In this article we intend to take a trip through the life path of Fritz Haber, a man who was known by important scientific inventions which earned him the Nobel Prize in Chemistry, but also that laid science at the service of the German war machine and further established the foundation of a new form of war, the chemical warfare.
\end{abstract}

$\mathrm{O}$

processo de síntese industrial de amoníaco, iniciado há cerca de 100 anos, tornou-se um pilar essencial da vida no planeta pela sua importância na produção de fertilizantes. No entanto, também serviu para sustentar a máquina de guerra, tornando-se num meio de destruição de vidas humanas. A ligar estas duas realidades está um acontecimento a I Guerra Mundial - onde as comunidades científicas se viram enredadas na promoção e desenvolvimento de novas armas, e um protagonista - Fritz Haber -, um cientista-guerreiro, cujo 80. ${ }^{\circ}$ aniversário da sua morte se assinala este ano. Nunca até então tinha havido uma ligação tão estreita entre a ciência e o poder militar e onde tão claramente se expuseram as duas faces da ciência. Neste artigo pretende-se fazer uma viagem pelo percurso de Fritz Haber, um homem que ficou conhecido pelas descobertas científicas que lhe valeram o prémio Nobel da Química mas também por ter posto a ciência ao serviço da máquina bélica alemã, lançando adicionalmente as bases de uma nova forma de guerra, a guerra química.

\section{INTRODUÇÃO}

Assinala-se este ano o 80. ${ }^{\circ}$ aniversário da morte de Fritz Haber, químico alemão, e figura controversa do seu tempo. Não será fácil definir Haber, tais as contradições em que viveu [1]. Terá sido ao mesmo tempo um herói e um vilão. Herói, pelas descobertas científicas que realizou, principalmente a descoberta e desenvolvimento de um processo industrial de síntese de amoníaco, com importante repercussão na produção de fertilizantes, e com o qual ganharia o Prémio Nobel da Química de 1918. Vilão por ter usado a ciência para fins menos nobres, nomeadamente por ter lançado as bases da guerra química e ter tido um papel activo na sua condução durante a I Guerra Mundial. Haber foi um judeu mas, ao mesmo tempo, um patriota alemão. Aqui, a contradição não será da responsabilidade do próprio, antes resulta das circunstâncias sociais e políticas de parte do período conturbado em que viveu. Finalmente, deparamo-nos com o aparente paradoxo de ter sido vítima dos nazis e, ao mesmo tempo, ser acusado de crimes de guerra. Haber terá sido admirado por uns e odiado por outros; muitos ainda, recusando-se a admirá-lo, não o condenam. No entanto, talvez para a maioria, a atitude mais fácil perante a sua figura seja a indiferença, preferindo ignorar a sua memória. Talvez por isso o nome de Haber se tenha desvanecido ao longo do tempo. Agora que se assinala, simultaneamente, o
80. ${ }^{\circ}$ aniversário da sua morte e os cem anos da eclosão da I Guerra Mundial, talvez seja a altura de não desviar o olhar e voltar a recordá-lo.

\section{JUVENTUDE}

Recuemos até 1868 e viajemos até Breslau, na Baixa Silésia, Prússia (actualmente a cidade de Wroclaw, na Polónia). A 9 de Dezembro desse ano, Fritz Haber vê a luz do dia no seio de uma família judaica, uma das maiores, mais antigas e unidas da cidade. Talvez o nome da criança ora nascida tenha sido inspirado no "velho Fritz", o epíteto dado pelos prussianos a Frederico II (Frederico, o Grande) que havia reinado durante 46 anos no século anterior. O seu pai, Siegfried Haber, era um comerciante de produtos químicos. A sua mãe, Paula Haber, era prima de Siegfried. O parto fora doloroso, difícil e com complicações que levaram a que Paula Haber viesse a falecer três semanas depois, quase ao raiar do novo ano. Enquanto criança e jovem, Haber viveu num período de expansão económica sem precedentes que fizeram do Império Alemão, resultante da chamada guerra franco-prussiana (1870-1871), o estado mais poderoso da Europa e que transformou a sua estrutura social. O bem-estar financeiro da família Haber, tal como a bem-sucedida integração dos judeus instruídos na sociedade privilegiada da época, terão possibilitado a Haber ter acesso ao teatro e 
a uma educação em filosofia clássica e literatura durante o Gymnasium (ensino liceal). Viria a interessar-se pela Química, tendo o seu tio Hermann cedido espaço no seu apartamento para realizar as primeiras experiências químicas. Em algum momento Haber teve a possibilidade de escolher entre gerir os negócios da família, lançar-se por conta própria na indústria ou seguir uma carreira académica. Quando terminou os seus estudos liceais acabou por decidir-se pela última, na área da Química, apesar das reticências do pai que preferia vê-lo dedicar-se aos negócios da família.

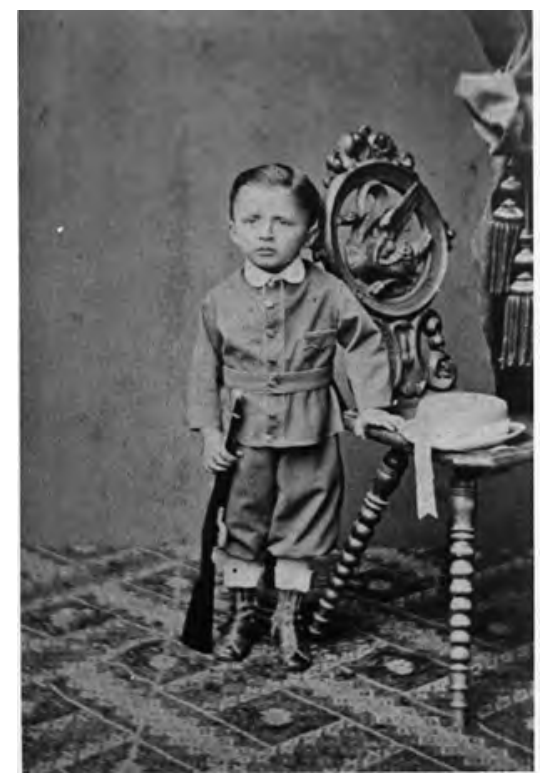

Figura 1 - Primeira imagem conhecida de Fritz Haber [1]

\section{Desassossego}

É assim que, no Outono de 1886, com 18 anos, Haber ruma às luzes da cidade de Berlim. Encontra uma cidade fervilhante, em claro processo de modernização, orgulhosamente carregando a marca da indústria. Entra na Universidade Friedrich Wilhelm (actual Universidade Humboldt) para estudar Química e Física, atraído pela reputação do seu director, August Wilhelm von Hoffmann, e de Hermann von Helmholtz. Haber veio à procura de liberdade e aventura intelectual. No entanto, encontra principalmente desapontamento. As aulas de Helmholtz seriam pouco inspiradoras e as aulas com o professor de Química seriam entediantes pois as experiências mostradas revelavam-se triviais e nada desafiantes aos olhos, exigentes, de Haber. Não estava muito satisfeito o jovem Haber com o seu tempo em Berlim até que o nome famoso de Robert Bunsen o atraiu para o instituto com o mesmo nome, em Heidelberg, onde passou o semestre de Verão de 1887. No entanto, Bunsen quase extinguia a chama da paixão de Haber pela Química... De facto, Bunsen era uma figura pouco acessível, do alto dos seus 76 anos, e com pouco interesse em inspirar os seus alunos na demanda dos segredos da natureza.

Entretanto, aproximava-se o vigésimo aniversário de Haber e, com ele, o dever militar. No Outono de 1888 junta-se ao regimento de artilharia de campanha na cidade natal de Breslau. $\mathrm{O}$ ano que passou a cumprir o serviço militar trouxeram-lhe a disciplina e a autoconfiança que iriam ser decisivas para o resto da vida. Vislumbrou também que a carreira militar poderia ser uma via para adquirir notoriedade, tendo aspirado a tornar-se oficial. À época, os oficiais prussianos gozavam de enorme prestígio: haviam sido herdeiros dos fundadores da nação, tinham unificado o Reich alemão e encarnavam as virtudes alemãs da disciplina e do dever. Haber concorreu, assim, para um lugar de oficial mas não conseguiu estar entre os eleitos. Ficou frustrado. Restava-lhe voltar aos estudos universitários em Berlim (fê-lo no Outono de 1889) e à agonia da incerteza no futuro. Durante os meses finais em Berlim dedicou-se ao campo florescente da Química Orgânica. Acabou por fazer uma dissertação sobre derivados de piperonal (1,3-benzodioxol-5-carboxaldeído), sob supervisão de Carl Liebermann, na Technische Hochschule Charlottenburg (actual Universidade Técnica de Berlim). A 29 de Maio de 1891, realizou os exames finais em Química, Física e Filosofia na Universidade Friedrich Wilhelm, tendo obtido um desempenho admirável em Filosofia, adequado no campo escolhido da Química e fraco em Física. Foi o suficiente para ser aprovado e poder ser tratado por Dr. Fritz Haber (Figura 2).

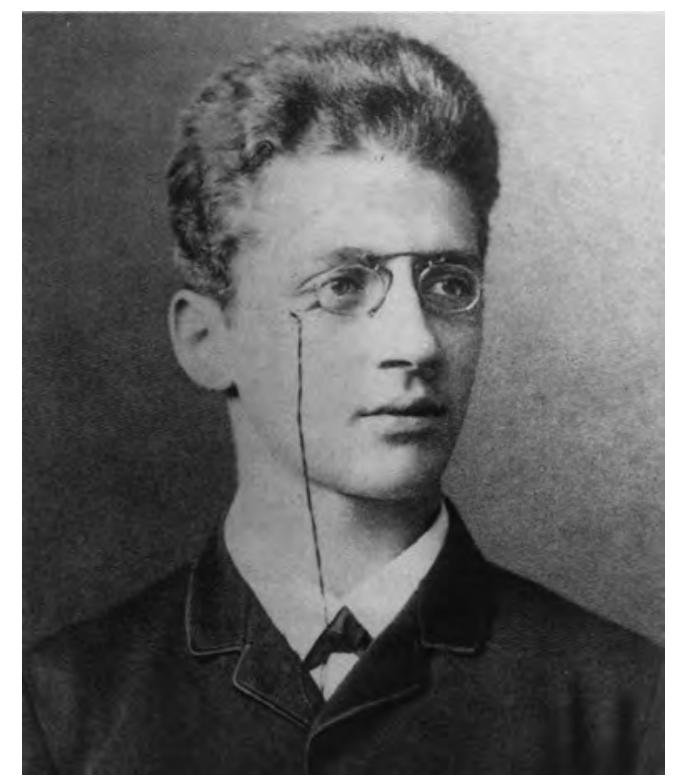

Figura 2 - Fritz Haber, pouco depois da sua graduação, em 1891 [1]

Após a graduação Haber concorre, juntamente com Richard Abegg, que havia conhecido durante o último ano de estudos universitários, a um lugar de assistente de investigação do mais reputado químico-físico da Alemanha, Wilhelm Ostwald, na altura professor na Universidade de Leipzig. Abegg foi aceite mas Ostwald nunca se tornou receptivo a receber Haber, que se viu num beco sem saída profissional. Concluídos os estudos universitários e sem planos para o futuro, Haber volta a Breslau, a casa do progenitor (atente-se ao paralelismo que os nossos estudantes graduados vivem nos dias de hoje!). Através dos conhecimentos empresariais do pai, Haber passa por uma sucessão de estágios de curta duração como aprendiz na indústria química. No Outono de 1891 tenta novamente a sorte no mundo universitário como assistente, desta vez em Zurique, mas haveria de ficar apenas um semestre queixando-se do autoritarismo do professor. Com vinte e três anos de idade, Fritz Haber volta para Breslau, aparentemente resignado a seguir as pisadas do pai no comércio. Trabalha com ele 
durante seis meses mas a parceria corre mal devido a uma decisão de gestão de Fritz Haber que se revelaria financeiramente desastrosa. Expulso pelo pai dos negócios, Fritz muda-se para a cidade de Jena, onde irá trabalhar como assistente de investigação de Ludwig Knorr na Universidade Friedrich Schiller. Infelizmente, Knorr trabalhava no domínio da Química Orgânica, uma área que Haber aprendeu a detestar. Descobriu, contudo, que a investigação era a sua verdadeira vocação e haveria de canalizar todas as suas forças nessa carreira. Durante o seu tempo em Jena, Haber haveria de converter-se ao cristianismo mas as motivações para o ter feito nunca foram esclarecidas [1].

\section{FIXAÇÕES}

Em 1894 chegam, finalmente, as boas notícias. No seguimento de um convite de Hans Bunte para ser seu assistente, Haber mudou-se para a Technische Hochschule em Karlsruhe na Primavera desse ano, tendo sido contratado em Dezembro. Karlsruhe era uma cidade ideal para Haber se fixar: tolerava bem os judeus e a universidade era financiada generosamente pelo governo local e tinha ligações privilegiadas com a maior companhia de químicos do país, a Badische Anilin \& Soda Fabrik, mais conhecida por BASF, situada nas proximidades. Haber haveria de permanecer na cidade e no instituto por dezassete anos, onde viveria tempos de glória e andaria nas luzes da ribalta. $\mathrm{O}$ Instituto de Química de Karlsruhe era uma instituição jovem, relativamente desprovida de formalidades ou daquilo que a tradição tem de menos positivo. Os supervisores deram-lhe uma liberdade considerável para trabalhar e Haber pôde, finalmente, emancipar os seus dotes científicos até onde a sua energia e a mente podiam alcançar. Através de trabalho árduo e de alguma sorte (muito dependente do primeiro), Fritz Haber mudou o seu historial científico de um previsível relato de um náufrago para um héroi (pouco) discreto. Haber trabalhou dia e noite, absorvendo o conhecimento dos seus pares, preparando palestras e realizando experiências que o levariam a publicar em revistas científicas de qualidade. Por vezes, contactava com o mundo real, visitando fábricas e laboratórios da indústria, estudando as suas práticas e problemas. Um dos seus trabalhos iniciais envolveu a combustão e decomposição de hidrocarbonetos levando-o à publicação do seu primeiro livro em 1896, intitulado Untersuchungen Experimental iiber Zerstetzung und Verbrennung von Kohenwasserstoffen (Investigações Experimentais sobre a Decomposição e Combustão de Hidrocarbonetos), que também serviu como tese de habilitação para a sua promoção a Privatdozent. Os anos seguintes foram o período mais produtivo de Haber, quer em termos do número total de publicações (quase cinquenta) quer na variedade de tópicos que pesquisou, abarcando as áreas da tecnologia química, electroquímica e química em fase gasosa. Em 1897 interessa-se pela teoria e aplicações industriais da electroquímica e, em 1898, publica o seu segundo livro, Grundriss der technischen Elektrochemie auf theoretischer Grundlage (A Base Teórica da Electroquímica Técnica). O livro trouxe-lhe reconhecimento no mundo académico tendo-se tornado Außerordentlicher Professor, apenas um degrau abaixo da categoria agora designada de Professor Catedrático. Quando abriu uma nova cátedra de Química-Física, o lugar foi ocupado por Max Julius Le Blanc, discípulo de Ostwald, o que provocou a ira de Haber. Fosse por causa do trabalho excessivo, personalidade ou ambição frustrada, os conhecidos “nervos” de Haber, que já o haviam atormentado antes, voltaram a atacar. Praticamente todos os anos, desde o Verão de 1898, Нaber refugiava-se num sanatório para tratar um cocktail de sintomas que incluíam exaustão física, irritabilidade, insónias, ansiedade e hiper-reactividade às críticas. No entanto, consta que os efeitos benéficos de tais retiros não duravam muito tempo...

Em 1899, o seu amigo Richard Abegg, discípulo de Walther Nernst, começa a leccionar na universidade da terra natal de Haber. Abegg haveria de ser orientador académico de uma jovem que foi a primeira mulher a doutorar-se na universidade de Breslau. O seu nome, Clara Immerwahr. Clara era filha de Philipp Immerwahr, primo de Georg Lunge com quem Haber trabalhara nos seus tempos em Zurique. Haber já conhecia Clara, aquando das suas estadas na sua terra natal. Algures em 1899 ter-se-á fixado de amores pela bela jovem, então com vinte e nove anos (Figura 3). Em 1901, durante um encontro da Sociedade Alemã de Electroquímica em Freiburg, Haber terá persuadido Clara (após muita insistência, diga-se de passagem) a juntarem as suas vidas. Meses depois, em Agosto do mesmo ano, os dois jurariam fidelidade eterna. Para Haber, o casamento foi uma bênção, conseguindo alguma estabilidade emocional e posição social. Pôde continuar o seu trabalho, ainda com maior paixão. Para Clara, contudo, o casamento provocou-lhe uma crise de identidade. Trocou uma possível carreira científica pelo papel aborrecido de dona-de-casa. A 1 de Junho de 1902 nasce o único filho de ambos, ao qual deram o nome do tio de Haber, Hermann.

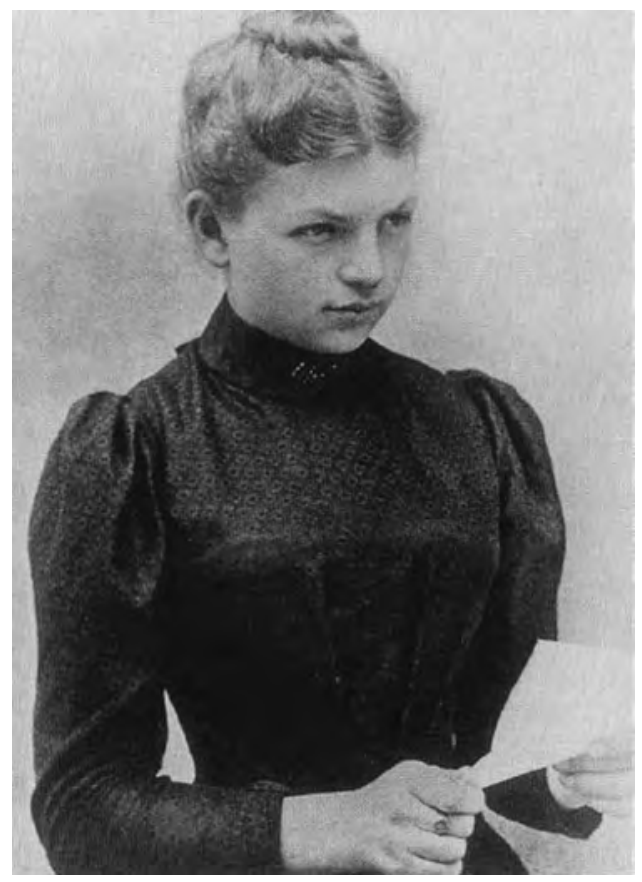

Figura 3 - Clara Immerwahr, com quem Haber casou em 1901 [1]

Nos anos seguintes, Haber publica inúmeros artigos científicos e livros em várias áreas. Em 1905 publica o livro, Thermodynamik Technischer Gasreaktionen (Termodinâ- 
mica de Reacções Gasosas Técnicas). Um ano depois, Walther Nernst publicou o seu "teorema do calor" que veio a ser conhecido mais tarde como a terceira lei da termodinâmica e que lhe valeu o Prémio Nobel da Química de 1920. As considerações que Haber escreveu no livro quase lhe permitiram chegar às conclusões de Nernst. Esteve tão perto que nunca se perdoou a si mesmo pela oportunidade perdida. O seu ciúme contribuiu para a rivalidade com Nernst, que se tornou mais acirrada em anos posteriores. No domínio da electroquímica, os seus trabalhos centraram-se na preparação de vários compostos orgânicos importantes, como o nitrobenzeno (1904), no estudo da célula combustível de hidrogénio-oxigénio (1907) e no estudo pioneiro sobre o eléctrodo de vidro (1909). O trabalho sobre o primeiro desses temas levou-o a publicar outro livro, intitulado Die elektrolytischen Prozesse der organischen Chemie (Os Processos Electrolíticos de Química Orgânica), publicado em 1910 e escrito em colaboração com Alexander Moser. Os trabalhos sobre o eléctrodo de vidro serviram de base para o desenvolvimento posterior do medidor de $\mathrm{pH}$. Contudo, seria o seu trabalho no domínio das reacções gasosas que haveria de o focar no trabalho científico que o tornou famoso, a síntese do amoníaco.

Por alturas da publicação do livro sobre a termodinâmica das reacções gasosas, em 1905, Haber ainda não havia atingido o topo da carreira. Entretanto, em 1906, o lugar de professor de Química-Física no instituto fica vago após Max Julius Le Blanc se ter mudado para a universidade de Leipzig. Era a oportunidade de Haber. No entanto, o processo de selecção dos candidatos levou a que fosse preterido em favor de Fritz Foerster, que já era professor na universidade de Dresden. A comissão de professores declarou que as qualificações científicas de ambos eram idênticas mas votou favoravelmente por Foerster tendo em conta as suas qualidades pessoais. Haber sentiu-se perseguido, muito provavelmente por causa da sua ascendência judaica ou por causa das inimizades internas que tinha gerado em virtude da sua ambição pessoal. Recorreu, por isso, aos seus amigos poderosos, nenhum mais bem colocado do que o ex-reitor da universidade Carl Engler, director do instituto e ex-membro do parlamento do estado de Baden. O caso chegou ao ministro da educação de Baden e, uma semana depois da votação da comissão, o nome de Haber surgiu no primeiro posto do concurso. A 10 de Agosto de 1906 foi assinada a ordem oficial de nomeação do Dr. Fritz Haber para a posição de Professor no serviço público do estado alemão. Finalmente, Haber tinha atingido a posição que sempre tinha desejado.

Em finais do século XIX, a questão do aumento da produção agrícola era tema de debate, nomeadamente na Europa [2]. A fertilização dos campos agrícolas era necessária e urgente para alimentar uma população mundial em crescimento. A Europa importava milhões de toneladas de fertilizante para o efeito, nomeadamente de nitrato do Chile. Porém, ao ritmo da extracção, dentro de pouco tempo as reservas esgotar-se-iam e urgia encontrar formas alternativas da sua obtenção. Sabia-se que o ar era uma fonte inesgotável de nitrogénio. No entanto, era necessário fixá-lo, isto é, combiná-lo, com outros elementos para que pudesse ser posteriormente transformado em fertilizantes. A forma de fixação mais simples seria a da sua combinação com hidrogénio, com formação de amoníaco. Haber viria a ter um papel fundamental neste processo. Muitos outros antes dele tiveram a mesma pretensão. Wilhelm Ostwald foi o que mais sucesso teve na demanda, tendo reivindicado em 1900 junto da BASF ser possível a produção de amoníaco a partir dos seus elementos, combinando temperaturas e pressões elevadas, a presença de um catalisador de ferro e a recirculação dos gases. No entanto, retirou a pretensão quando Carl Bosch, um jovem químico ao serviço da empresa, mostrou que a pequena quantidade de amoníaco que se formava não se devia à fixação do nitrogénio do ar mas sim à hidrogenólise do nitreto de ferro $\left(\mathrm{FeN}_{3}\right)$, formado durante o tratamento prévio do catalisador antes das experiências.

O trabalho de Haber na síntese do amoníaco terá começado em 1903, após um inesperado pedido da companhia de Viena Österreichische Chemische Werke, dos irmãos O. e R. Margulies. Os industriais tinham detectado traços intrigantes de amoníaco na sua fábrica de produtos químicos e perguntaram-se se não tinham, por acaso, descoberto uma forma até então desconhecida de produzir tão valioso produto. Pediram a Haber para os ajudar. Este, após alguma resistência inicial, aceitou a oferta (a companhia austríaca ofereceu-lhe um suporte financeiro generoso...) e iniciou as suas experiências aproveitando os trabalhos dos colegas que o precederam. Começou por estudar a proporção de amoníaco obtida no equilíbrio a temperaturas elevadas $(1000$ C), à pressão atmosférica e usando ferro como catalisador. A proporção obtida revelou ser muito baixa (logo, a reacção seria industrialmente pouco viável) para justificar mais estudos e informou os irmãos Margulies do facto. Em 1905 publica, juntamente com o seu assistente Gabriel van Oordt, os resultados deste trabalho. Haber teria colocado uma pedra sobre o assunto se não fosse a intromissão de Nernst. Através de carta, no Outono de 1906, este contestou o valor da proporção de amoníaco no equilíbrio obtido por Haber pois não batia certo com o valor previsto com base no seu "teorema do calor". Disse a Haber ter pedido a um estudante para repetir a experiência, agora usando gases pressurizados. Referiu que tinha obtido um ponto de equilíbrio significativamente diferente do das experiências de Haber e que iria apresentar os resultados aquando do encontro da Bunsen Society for Applied Physical Chemistry, a realizar na Primavera seguinte. A perspectiva de correcção pública por Nernst era intolerável. Haber entra em acção e repete as experiências mas de forma mais elaborada usando diferentes tamanhos de recipientes e diferentes catalisadores. Os novos resultados ainda não concordavam com os de Nernst mas estavam bem mais próximos. Adivinhava-se uma luta titânica no encontro da Primavera. Nernst contestou publicamente os primeiros resultados de Haber ao que este retorquiu apresentando os novos resultados obtidos. Mais uma vez Nernst contestou veementemente os novos resultados (referindo-se a eles como altamente incorrectos), apesar dos valores obtidos serem bastante mais próximos do previsto com base na formulação termodinâmica do próprio Nernst... Não teria sido fácil lidar com as críticas, principalmente vindas de alguém com a reputação de 
Nernst. Para Haber, e talvez também para Nernst, a disputa tornou-se um duelo pessoal, uma questão de ego e estatuto.

Haber não poderia dar-se por vencido. Voltaria ao laboratório e dedicar-se-ia à captura do nitrogénio do ar com muito mais determinação. O amoníaco tornar-se-ia uma obsessão quase... demoníaca. Haber adquiriu um compressor que lhe permitiu trabalhar com os gases a pressões duzentas a trezentas vezes mais elevadas do que a pressão atmosférica. Nernst já havia comprimido os gases nas suas experiências, mas apenas de forma moderada, e havia produzido maiores quantidades de amoníaco. Haber terá pensado que talvez em condições ideais de pressão e temperatura e utilizando uma catalisador adequado poderia obter grandes quantidades de amoníaco, e o arrefecimento posterior para o obter na forma líquida permitiria isolá-lo. Quanto mais Haber pensava sobre o assunto, mais ele sentia que valia a pena prosseguir. Teve a sorte de contar com um novo assistente britânico, Robert Le Rossignol, que demonstrou possuir uma grande apetência para o design engenhoso de equipamento experimental. Rapidamente descobriram a vantagem de se trabalhar a maiores pressões. No entanto, havia o inconveniente dos custos económicos industriais associados a estas condições. Assim, seria preferível trabalhar a pressões mais baixas, mas o consequente deslocamento do equilíbrio em desfavor da quantidade de amoníaco teria de ser compensado com o uso de temperaturas mais baixas, desfavorecendo a velocidade da reacção. Após fixarem as condições razoáveis de pressão e temperatura virariam a sua atenção para a escolha de um catalisador adequado e para um sistema apropriado de circulação de gases.

Poucos anos antes, em 1903, tinha emergido o processo Birkeland-Eyde (oxidação do nitrogénio atmosférico por sobreaquecimento do ar através de um arco eléctrico) como um método promissor de fixação de nitrogénio. A oxidação produz óxido nítrico que, por oxidação posterior a dióxido de nitrogénio e dissolução em água, produz ácido nítrico. No entanto, os custos energéticos envolvidos eram extraordinariamente elevados e a sua viabilidade económica duvidosa. Haber e um outro seu pupilo, A. König, abraçaram o estudo da produção de NO através da utilização de arco voltaico tendo publicado um artigo em 1907 em que defendiam o uso de temperaturas mais baixas para aumentar a eficiência do processo. Rapidamente o trabalho chamou a atenção da BASF. Carl Engler, colega de Haber na Technische Hochschule e membro da administração da BASF, sondou-o para trabalhar para a empresa. O acordo haveria de chegar a 6 de Março de 1908. Na realidade foram dois acordos: o primeiro, entre Haber, König e a BASF, em torno da síntese de gases nitrogenados pelo método do arco voltaico, pelo qual Haber ganharia dez mil marcos após aprovação da patente; o segundo, entre Haber e a BASF, garantiria ao primeiro seis mil marcos por ano até Fevereiro de 1911 (mais tarde alargado a Outubro de 1914), para apoiar os trabalhos sobre a síntese de amoníaco. Todas as descobertas patenteáveis tornar-se-iam propriedade da BASF e Haber receberia 10\% dos ganhos durante a duração das patentes. À época, a BASF estava verdadeiramente interessada em melhorar o processo Birkeland-Eyde e só com grande relutância apoiou os trabalhos da síntese do amoníaco. Haber sabia, contudo, já em 1908, que a oxidação do ar por arco eléctrico não era o caminho para a fixação de nitrogénio em grande escala. Os seus trabalhos neste assunto, com a colaboração de três assistentes, prosseguiram até 1910 e culminaram com a publicação de vários artigos sumariando vários anos de pesquisa.

Entretanto, a pesquisa na síntese de amoníaco foi incrementada, mais uma vez com a ajuda de Nernst. Para alarme de Haber, Nernst anunciou que acreditava que podia ser possível criar amoníaco pois estava a trabalhar numa solução para o problema que tornaria todo o comércio de nitratos obsoleto. Felizmente para Haber, os esforços de Nernst não resultaram mas deixaram-no em pânico, tendo exortado os seus novos patrões da BASF para a necessidade de conjugarem esforços na síntese do amoníaco. No entanto, não era fácil, à época, trabalhar com pressões e temperaturas elevadas. Válvulas especiais tiveram de ser produzidas para controlar o fluxo de gases, tendo valido a habilidade extraordinária de Le Rossignol para as fazer. Os estudos sobre a circulação dos gases resultaram na primeira patente sobre a síntese de amoníaco. A patente $\mathrm{N}^{\circ}$ 235421, publicada em 8 de Junho de 1911, ficou conhecida como a "patente da circulação". A reivindicação aludia a um "processo de síntese de amoníaco a partir uma mistura apropriada de nitrogénio e hidrogénio, a pressão constante, usando catalisadores aquecidos e transferência de calor dos gases da reacção para a mistura de gases à entrada” [2].

A fim de obter rendimentos que tornariam o processo comercialmente viável, era imperativo descobrir catalisadores metálicos que induzissem a conversão rápida a temperaturas entre 500 e $600{ }^{\circ} \mathrm{C}$. Os candidatos naturais à época seriam o crómio, manganês, ferro ou níquel mas a escolha final de Haber recaiu no ósmio. Porquê o ósmio? Talvez porque na altura Haber era também consultor de uma empresa de fabrico de lâmpadas incandescentes, a Deutschen Gasglühlicht-Aktiengesellschaft, que usava ósmio nos filamentos (mais tarde viria a ser substituído por tungsténio) e, portanto, teria acesso facilitado ao metal. O uso de ósmio como catalisador foi experimentado na terceira semana de Março de 1909, tendo permitido melhorar o rendimento da síntese de amoníaco para 6\%. Quando arrefecido a temperaturas negativas, o amoníaco liquefez-se e correu por um tubo para um colector. Haber, eufórico, informou os directores da BASF desse facto, tendo insistido com eles para a necessidade de adquirir todo o ósmio na posse da Deutschen Gasglühlicht-Aktiengesellschaft (a empresa tinha acumulado, à época, a maior parte do ósmio produzido) para se precaverem do previsível aumento de preço. No entanto, os directores da BASF mantinham o seu cepticismo quanto à viabilidade comercial do processo. Carl Enger intercedeu junto da direcção da BASF e, a 26 de Março de 1909, uma delegação composta por Henrich von Brunck (director de investigação), August Bernthsen (director dos laboratórios) e Carl Bosch (o mesmo que tinha desacreditado Ostwald cerca de uma década antes sobre o mesmo assunto) visitou o laboratório de Haber. Quando este os informou das condições para a produção de amoníaco, 
nomeadamente o uso de pressões da ordem das $100 \mathrm{~atm}$, Bernthsen pôs as mãos à cabeça, horrorizado, tendo referido que ainda no dia anterior "tivemos uma autoclave a uma pressão de apenas 7 atm a voar pelo ar!" [2]. Felizmente, a reunião acabou por correr bem e Carl Bosch assumiu a responsabilidade, na empresa, pelo acompanhamento do processo. Cinco dias depois desta reunião auspiciosa, nova patente foi registada, a chamada "patente do ósmio".

Haber continuou a investigação tentando afinar as condições experimentais, nomeadamente procurando catalisadores mais eficientes. A escolha recaiu sobre o urânio, com o qual obteve rendimentos de formação de amoníaco de $10 \%$, valor bastante apelativo em termos comerciais e nova patente foi registada. A 2 de Julho do mesmo ano, a montagem experimental construída produziu amoníaco de forma ininterrupta durante 5 horas, com um rendimento de $80 \mathrm{~g} / \mathrm{h}$ de $\mathrm{NH}_{3}$ (Figura 4). A excitação foi grande no seio das pessoas que testemunharam o evento, alastrada ao resto das pessoas do departamento (Figura 5). A terceira patente-chave de Haber sobre a síntese de amoníaco, a n. ${ }^{\circ}$ 238450, viria a ser publicada em 28 de Setembro de 1911, tendo ficado conhecida como a "patente da pressão elevada”. A reivindicação refere “o processo para a produção de amoníaco a partir dos seus elementos, por via catalítica e sob pressão e temperatura elevada, cuja característica é a de que a síntese se realiza sob pressão muito elevada de 100 atm, mas sendo eficiente a 150-250 atm ou superior" [2]. Neste momento, não havia dúvidas sobre a viabilidade da síntese de amoníaco a partir dos seus elementos e von Brunck convenceu-se finalmente que a BASF deveria comprometer os recursos necessários para a comercialização. O passo seguinte foi fazer o scale up da montagem experimental de Haber para a escala piloto e assegurar o abastecimento de nitrogénio e hidrogénio. Foi, contudo, dada a recomendação de tentar substituir os catalisadores (ósmio ou urânio) por metais mais baratos e de mais fácil acessibilidade. A Carl Bosch coube a tarefa de fazer o scale up. O nitrogénio necessário viria a ser obtido através do processo de destilação fraccionada do ar, devido a Linde, e o hidrogénio através do chamado gás de água, obtido pela

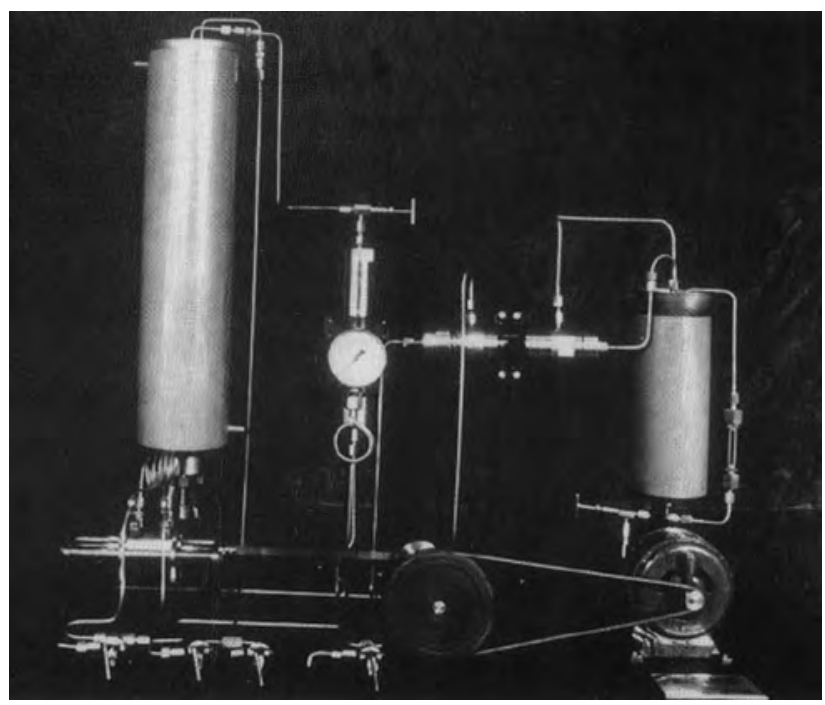

Figura 4 - Equipamento de Haber-Le Rossignol para a síntese de amoníaco [3]

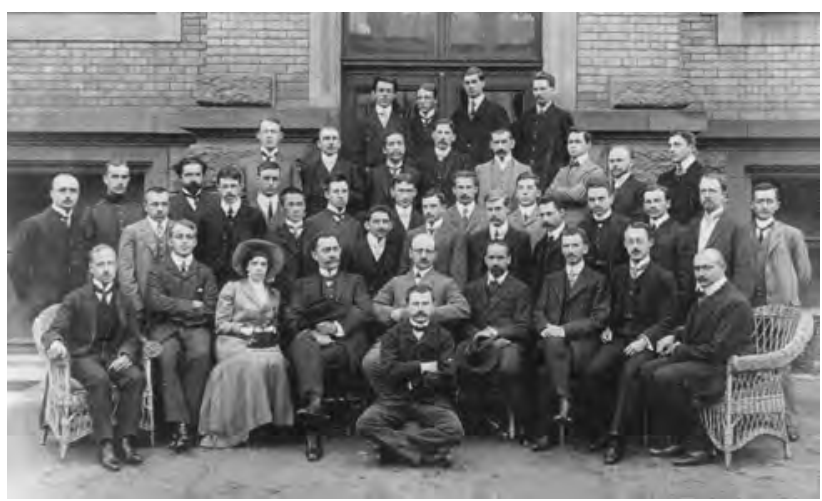

Figura 5 - Departamento de Haber na Technische Hochschle Karlsruhe, 1908. Fritz Haber sentado ao meio (quinto a contar da esquerda, imediatamente atrás da pessoa sentada à frente) e Le Rossignol, também sentado, é o segundo a contar da esquerda. [3]

reacção do coque com vapor de água. A tarefa de encontrar um catalisador adequado e barato coube a Alwin Mittasch, assistente de Bosch, e seus colaboradores. O ferro viria a ser o eleito, não na forma pura tal como Ostwald tinha usado centenas de vezes anos antes durante as suas experiências, mas sob a forma de "ferro impuro", uma mistura de $\mathrm{Fe}, \mathrm{Al}_{2} \mathrm{O}_{3}, \mathrm{~K}_{2} \mathrm{O}$, $\mathrm{CaO}$ e $\mathrm{MgO}$.

Entretanto, várias empresas (Kunheim, Griesheim-Elektron, Hoechst), bem como Fritz Jost, colaborador de Nernst, que em 1906 havia obtido a amoníaco a 50 atm, contestaram as patentes básicas de Haber. Curiosamente, Haber foi defendido por Nernst (a BASF, astuciosamente, manipulou Nernst tendo-lhe oferecido um "honorário" anual de dez mil marcos durante cinco anos e ele prontamente empenhou-se em defender a patente de Haber). A Hoechst recrutou Ostwald para a sua causa. Os rivais Haber e Nernst ficaram do mesmo lado da barra em tribunal. Haber e a BASF venceram a disputa a 4 de Março de 1912. Quis o destino que nesse dia estivessem presentes na sala do tribunal um Prémio Nobel (Ostwald, 1909) e três futuros Prémios Nobel: Haber (1918), Nernst (1920) e Bosch (1931). Não consta que tal se tenha repetido.

Carl Bosch viria a estar ligado indubitavelmente ao processo de síntese industrial mais importante do mundo. De facto, transformou a montagem experimental de Haber e Le Rossignol num sucesso comercial num espaço de tempo extraordinariamente curto. Em apenas quatro anos passou-se de um conversor da altura de 75 centímetros, montado na bancada do laboratório de Haber na Technische Hochschule Karlsruhe e produzindo 80-100 g/h de $\mathrm{NH}_{3}$, para um conversor da altura de oito metros, instalado na primeira fábrica de amoníaco em Oppau, perto de Ludwigshafen, com uma produção de $200 \mathrm{~kg} / \mathrm{h}$ de $\mathrm{NH}_{3}$. Durante o primeiro ano completo de funcionamento da fábrica de Oppau, em 1914, fixaram-se cerca de 20 toneladas de nitrogénio por dia. Pouco tempo depois, uma fábrica de muito maior dimensão haveria de começar a laborar em Leuna, perto de Halle. O trabalho da síntese do amoníaco foi um dos marcos científicos mais importantes do século $\mathrm{xx}$ : revolucionou a indústria dos fertilizantes, sem a qual não teria sido possível a expansão da população mundial de 1,6 biliões de pessoas em 1900 para os cerca de 7 biliões de hoje. Em 2013, a pro- 
dução anual de amoníaco foi estimada em 140 milhões de toneladas, dos quais cerca de $80 \%$ foram usados na indústria dos fertilizantes [4].

\section{Patriotismo}

Em 1888, Wilhelm II ascendeu ao trono da Alemanha. Era neto da Rainha Vitória de Inglaterra e parente de muitos monarcas europeus, nomeadamente do rei Jorge V de Inglaterra e do czar Nicolau II, o último monarca do Império Russo antes da Revolução de 1917 que aboliu a monarquia. Wilhelm II era um jovem impetuoso, dominado por visões de um destino grandioso para a Alemanha, tendo a propensão para provocar outras nações com discursos agressivos e atitudes belicistas. O imperador alemão considerava-se um monarca avançado, dos tempos modernos, pois promovia entusiasticamente as artes e as ciências, bem como a educação pública e o bem-estar social. Em 1910 convoca os homens poderosos da nação germânica, industriais e banqueiros, para o apoiarem numa política assente no casamento entre a ciência e o patriotismo. A ideia, sugerida pelo teólogo alemão Adolf von Harnack, seria colocar a ciência (e os homens por trás dela) ao serviço da pátria alemã. Para tal, Harnack havia proposto ao imperador que estabelecesse uma série de instituições de investigação de elite, os chamados “Institutos Kaiser Wilhelm”, suportados financeiramente pelos industriais e banqueiros alemães. Um dos homens presentes na reunião era o banqueiro Leopold Koppel que ouviu a proposta com muito interesse. Ele viu uma oportunidade de ganhar a gratidão e confiança do imperador e, ao mesmo tempo, potenciar a ciência para seu próprio benefício. Koppel conhecia o homem certo para levar a cabo seu plano. Ao regressar ao seu escritório, chamou Fritz Haber a Berlim para lhe revelar a sua proposta.

Koppel conhecia Haber dos tempos em que este era consultor técnico da Deutschen Gasglühlicht-Aktiengesellschaft, uma das empresas controladas por ele e que forneceu o ósmio para os estudos de Haber sobre a síntese de amoníaco. Era uma oferta a que Haber não podia resistir. Teria um orçamento operacional generoso para gerir, o estatuto de oficial do estado, uma cátedra na Universidade de Berlim e, como cereja no topo do bolo, a possibilidade de ser membro da prestigiosa Academia de Ciências da Prússia. Mais tarde, Koppel haveria de informar o imperador que estava disposto a financiar a totalidade da construção do Instituto Kaiser Wilhelm para a Físico-Química e Electroquímica e também uma grande parte dos seus custos operacionais anuais. Só havia uma condição: que Fritz Haber fosse o seu director-fundador. Haber aguardou vários meses pelos desenvolvimentos até que recebeu a notícia que a sua vida iria mudar. Em Julho de 1911 muda-se, com a mulher e filho, para Berlim para ocupar o lugar de director do Instituto (Figura 6), hoje Fritz-Haber-Institut der Max-Planck-Gesellschaft.

Em Berlim, Fritz Haber metamorfosear-se-ia de grande investigador científico para cidadão Fritz e patriota. Haber havia chegado a Berlim numa altura de fervor imperialista e sob uma atmosfera de uma possível guerra iminente. A expansão económica exigia expansão territorial e as provo-

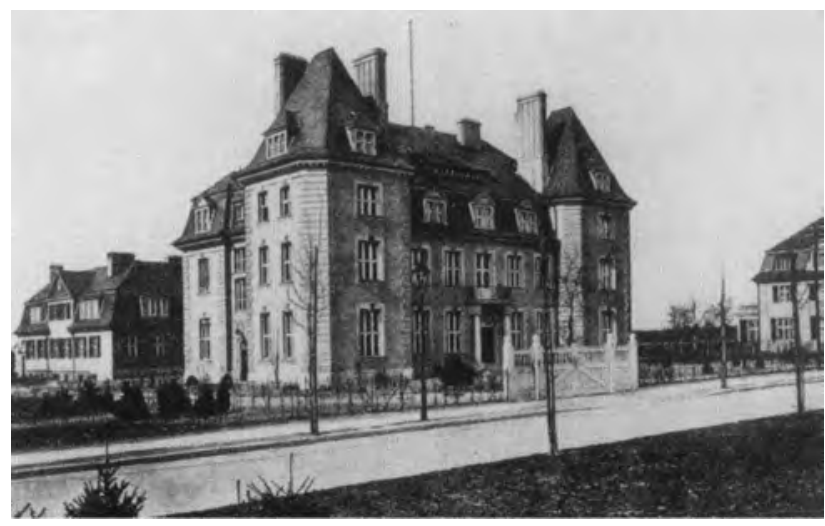

Figura 6 - Instituto Kaiser Wilhelm para a Físico-Química e Electroquímica (ca 1912). Mansão de Haber à direita. [3]

cações alemãs contra os países vizinhos e seus interesses, nomeadamente britânicos e franceses, eram recorrentes. Como membro da elite da nação, o sentimento patriótico de Haber foi aumentando, tendo concordado com os seus pressupostos: que o seu país, cercado por inimigos, exigia lealdade; que as suas forças armadas em crescimento podiam servir a causa da paz; que a nação, se unida, nunca poderia ser derrotada. Os dias no laboratório tornar-se-iam cada vez mais escassos já que a actividade de gestão lhe tomava praticamente todo o tempo. Contudo, não saiu do laboratório contra a sua vontade. Deixou-o voluntariamente, trocando-o por outros valores: poder, honrarias e a influência nacional. Haber aceitou e, por vezes, exigiu um lugar nos conselhos do governo, aconselhando os líderes da Alemanha nas áreas da ciência, indústria e até mesmo da guerra. Foi abrindo caminho nos círculos governamentais através da sua inteligência e força de personalidade. Acabaria por ser nomeado Geheimrat, ou conselheiro particular, um título originário dos tempos feudais que sugeria um papel como conselheiro do trono.

Em Dahlem, na extremidade ocidental de Berlim, crescia entretanto um complexo de edifícios que haveria de albergar uma grande comunidade científica. Seria a almejada "Oxford alemã" em que Fritz Haber seria, em muitos aspectos, personalidade central. Haber persuadiu outros cientistas a juntarem-se a ele em Dahlem, nomeadamente Richard Willstätter (Prémio Nobel da Química de 1915) e Albert Einstein (Prémio Nobel da Física de 1921). O primeiro haveria de ser o director do Instituto Kaiser Wilhelm para a Química tendo-se tornado a sua alma gémea e defensor. O segundo haveria de tornar-se director do Instituto Kaiser Wilhelm para a Física. Einstein era a antítese de Haber em termos de personalidade. Apesar de Einstein ser um dos principais críticos do seu patriotismo exacerbado, eram amigos. Segundo consta, Haber teria agido, por vezes, como confidente de Einstein e intermediário entre este e sua esposa Mileva nos seus conflitos conjugais. O casamento entre ambos haveria de terminar em separação.

Por essa altura, outro conflito, de maiores proporções, aproximava-se da Europa e outras separações haveriam de ocorrer. Enquanto Albert Einstein se despedia da vida conjugal com Mileva em Berlim, o Arquiduque Francisco Fernando, herdeiro do trono real da Áustria, despedia-se 
da vida em Sarajevo, morto por uma saraivada de tiros disparados por um cidadão sérvio. O orgulho, medo e rivalidades nacionais que se acumularam ao longo do tempo na Europa haveriam de retumbar numa força destrutiva. Uma morte, ou melhor, duas já que a jovem arquiduquesa também faleceu, haveria de originar milhões de vítimas em quatro anos de morticínio dificilmente explicáveis. As duas grandes alianças da Europa colocaram-se em lados opostos da barricada. A Alemanha aliou-se à Áustria. A Rússia, apoiada pela França e, indirectamente, pela Grã-Bretanha, mobilizou as suas forças armadas em defesa da Sérvia. A 1 de Agosto, a Alemanha declara guerra à Rússia e, dois dias depois, à França. Um sentimento de patriotismo varreu toda a Alemanha e os académicos foram apanhados na onda. O de Haber levou-o a assinar, em Outubro de 1914, o manifesto "Pela Civilização", do dramaturgo e poeta Ludwig Fulda. O manifesto proclamava o militarismo alemão como salvador da cultura germânica ("o exército alemão e os alemães são um só”) [1]. Assinaram o documento 93 cientistas. Entre eles encontravam-se, além de Fritz Haber, os três antigos Prémios Nobel Paul Ehrlich (1908, Fisiologia), Emil Fischer (1902, Química) e Wilhelm Ostwald (1909, Química) e dois que viriam a recebê-lo no futuro, Richard Willstatter (1915, Química) e Walther Nerst (1920, Química). Todos estavam convencidos de que a Alemanha não tinha qualquer responsabilidade pelo deflagrar da guerra e que simplesmente tinha de se defender. Pela mesma altura, um contramanifesto apelando à unidade europeia e ao fim da guerra, assinado por Albert Einstein, viria a ter quatro assinaturas...

Os alemães acharam que a guerra seria rápida e a exaltação cegou-os. Porém, o entusiasmo durou pouco uma vez que se tornou óbvio que a Alemanha não iria conseguir uma vitória rápida na frente ocidental. Após a perda terrível de vidas humanas trazida por um enorme gasto de munições durante a primeira Batalha do Marne (6 - 9 Setembro, 1914), percebeu-se que a guerra de trincheiras exigiria mais explosivos do que o previsto. A fonte imediata de nitratos necessária para a produção de explosivos provinha do Chile. No entanto, as linhas de abastecimento através do Atlântico estavam agora bloqueadas por navios de guerra britânicos. Portanto, a fim de ser capaz de travar uma guerra prolongada, a Alemanha teria que reestruturar grande parte da sua base de recursos. Sucediam-se reuniões no Ministério da Guerra alemão envolvendo cientistas e industriais, entre eles, Fritz Haber e Carl Bosch. Era imperioso alimentar a máquina de guerra alemã com combustível e munições. Haber ofereceu os seus préstimos e os recursos do instituto que dirigia em Berlim ao serviço do seu país. Carl Bosch asseguraria os préstimos da BASF e outros assegurariam os préstimos de outras fábricas. Estavam lançados os dados para a promoção de uma aliança entre a ciência, a indústria e a máquina bélica alemã. Esta seria a primeira contribuição de Fritz Haber para o esforço de guerra. Numa questão de meses foram construídas fábricas para produção de nitratos. O amoníaco, que tinha como principal destino a produção de sulfato de amónio para ser usado como fertilizante, permitindo "fazer pão a partir do ar" e alimentar seres humanos, deu lugar à produção de nitratos e outros explosivos que permitiam produzir "pólvora a partir do ar” e alimentar a máquina de guerra e o sofrimento humano. Este é um exemplo paradigmático onde se revelam os benefícios e os malefícios da ciência e a eterna relação entre a ciência e a consciência (ou a falta dela). Jorge Calado, no seu recente ensaio sobre limites da ciência [5] refere Fritz Haber como tendo sido "o primeiro a dar a trincadela na maçã (lustrosa por fora mas envenenada por dentro) da ciência potencialmente perigosa nas suas aplicações...”.

A maçã seria apetitosa pois Haber, fazendo uso do seu fervoroso patriotismo, foi mais longe e aliou as suas qualidades científicas às de liderança e de organização, concebendo e supervisionando uma nova forma de guerra no teatro de operações durante a I Guerra Mundial: a guerra química. A ideia tinha partido de um oficial alemão, Max Bauer, que sugeriu a utilização de gases nocivos para obrigar os soldados inimigos a saírem das trincheiras (as tropas francesas haviam utilizado bombas de bromoacetato de etilo em Agosto de 1914 para o mesmo fim). Fizeram-se reuniões com químicos proeminentes, entre eles Walther Nernst e Carl Duisberg, na altura chefe da Bayer. Foi proposta a utilização de clorossulfonato de $o$-anisidina, altamente irritante, que haveria de ser testada no final de Outubro numa zona próxima de Neuve-Chapelle, França, com resultados (militarmente) interessantes. Nos primeiros meses da guerra, franceses e alemães haveriam de utilizar vários gases lacrimogéneos, não letais, nas suas munições. Para o alto comando alemão, contudo, era importante que fossem usadas armas químicas mais letais, tendo Haber assumido a responsabilidade de coordenar o seu desenvolvimento.

No início de 1915, Haber sugeriu a utilização de cloro no campo de batalha ao alto comando alemão, que aprovou e o encarregou da sua implementação. Fritz Haber, agora um cientista-soldado sem patente militar mas com grande autoridade, haveria de estar na frente de batalha para supervisionar pessoalmente a sua utilização (Figura 7). Rodeou-se de um grupo de pessoas que viria a constituir uma unidade especial do exército para o efeito, o $35 .^{\circ}$ Regimento Pioneer [6]. A lista de Haber incluía Otto Hahn, Wilhelm Westphal, Erwin Madelung, James Franck e Gustav Hertz. Três deles haveriam de ser futuros Prémios Nobel: Hahn (1944, Química), Franck (1925, Física) e Hertz (1925, Física). A 22 de Abril de 1915, em Ypres (França) foi lançado o primeiro ataque. Nesse dia, às 17 h e sob vento favorável, foram abertos mais de 5000 cilindros contendo 168

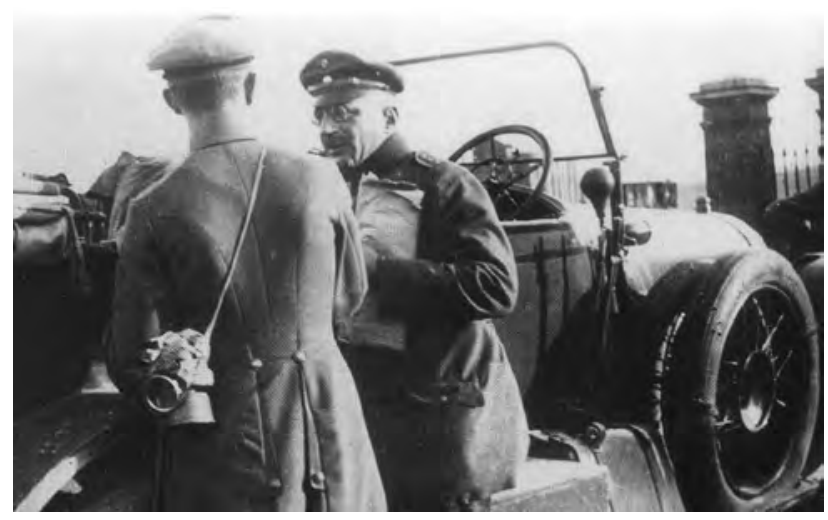

Figura 7 - Haber na frente de guerra durante a I Guerra Mundial [3] 
toneladas de cloro. A nuvem amarelo-esverdeada formada, com cerca de quinze metros de altura e seis quilómetros de comprimento, haveria de causar milhares de vítimas [6]. O ataque foi repetido dois dias depois, causando ainda mais vítimas. Uma nova era tinha nascido no uso da Química. A letalidade do ataque com cloro em Ypres levou o alto comando militar alemão a adoptar a guerra química e Haber foi promovido, por decreto imperial, ao posto de capitão. Vinte anos depois da sua primeira tentativa, o filho do comerciante judeu de Breslau tornava-se, finalmente, um oficial. Uma das vítimas indirectas do trabalho de Haber foi a sua mulher Clara. Quando descobriu o envolvimento do marido na guerra química, que ela considerava como "abominação da ciência e um sinal de barbárie” [1], o casamento, já de si vacilante devido ao seu papel frustrante de dona-de-casa, tornou-se insustentável. Dias depois de Haber ter ostentado com orgulho o seu novo uniforme, na noite de 1 para 2 de Maio, Clara decide morrer usando a pistola do exército do marido para o efeito. O corpo, inanimado no jardim da mansão, foi encontrado pelo filho de ambos, Hermann, com 13 anos. No dia seguinte, Haber, sem possibilidade de gozar licença, partiria para a frente oriental, para se juntar ao seu regimento.

Em meados de 1915, Fritz Haber era já considerado o czar da guerra química e o seu instituto parecia um acampamento militar: chegaram a trabalhar lá 1500 pessoas, 150 das quais cientistas. Entretanto, no campo de batalha, o cloro haveria de dar lugar ao fosgénio e, mais tarde, ao gás mostarda (ou iperite), gases bastante mais tóxicos. Haber considerou o uso das armas químicas como um importante marco na "arte da guerra" e viu o seu efeito psicológico como fundamental ao referir que "todas as armas modernas, embora aparentemente destinadas a causar a morte do adversário, na realidade, devem o seu sucesso ao vigor com que temporariamente quebram a força psicológica do adversário” [1]. Argumentou ainda que a guerra química era mais "humana" do que o convencional, uma vez que encurtaria a guerra. A realidade viria a desmenti-lo. Os aliados usariam o seu próprio arsenal químico e a guerra haveria de prolongar-se. A guerra química tornou-se, assim, um completo fracasso militar, não fornecendo nenhuma vantagem para qualquer das partes. Pelo contrário, provocou um sofrimento incomensurável, que continuou por dezenas de anos na pele dos que sobreviveram aos ataques com produtos químicos. O que haveria de pôr fim à guerra não foi o uso das armas químicas, mas sim o colapso económico da Alemanha e a exaustão das forças alemãs no campo de batalha. No final de Setembro de 1918, os comandantes militares declararam a guerra perdida e solicitaram aos civis que negociassem um acordo de paz. Entretanto, ainda nos tempos de cólera, Haber encontrou tempo para o amor. Em 1917 haveria de casar com Charlotte Nathan, uma gerente de negócios na Sociedade Alemanha 1914, um clube que Haber frequentava quase todos os dias quando estava em Berlim (Figura 8). Tiveram dois filhos, Eva e Ludwig. Ludwig (Lutz) tornou-se um respeitado historiador de economia, tendo escrito muitos anos depois um livro em que retracta o papel do pai no programa de guerra química durante I Guerra Mundial [7].

Um ano depois do armistício, havia rumores que Haber faria parte de uma lista de 900 alegados criminosos de guerra

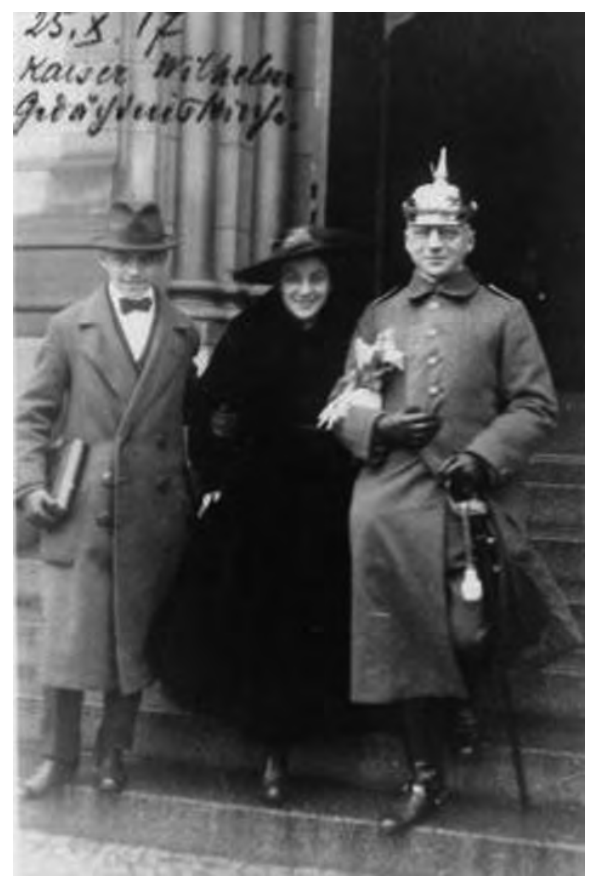

Figura 8 - Haber, Nathan e o filho de Haber, Hermann (à esquerda), a seguir à cerimónia de casamento [1]

que os aliados queriam deter e levar a julgamento. Haber deixou crescer a barba e fugiu para a Suíça com a família (Charlotte, Hermann e Eva) na esperança de garantir imunidade judicial. O tempo foi passando e, como os rumores não se confirmaram, poucos meses depois regressou a Berlim e ao seu instituto. Haber continuou ligado ainda durante algum tempo depois da guerra ao desenvolvimento e produção de armas químicas. Para ludibriar os controlos instituídos pelo Tratado de Versalhes, parte do programa havia sido transferido para o Instituto Biológico Imperial da Agricultura e Florestas onde antigos associados de Haber desenvolviam insecticidas e estudavam os seus efeitos em animais. Entre os agentes então desenvolvidos estariam vários insecticidas à base de cianeto de hidrogénio, incluindo o Zyklon B, mais tarde usado pelos nazis nos campos de extermínio de judeus durante a II Guerra Mundial. Ironicamente, vários membros da família de Haber contar-se-iam entre as vítimas. Haber também teve uma participação activa na tentativa de construção de uma fábrica de armas químicas na Rússia, no âmbito de uma cooperação secreta entre as autoridades militares alemãs e russas que não se viria, entretanto, a concretizar por questões financeiras, tendo o projecto sido abandonado em 1926. Tanto quanto se sabe, este terá sido o último episódio do envolvimento de Haber no mundo sombrio do armamento químico.

A sombra do envolvimento com a guerra química pairou sobre Haber para o resto da sua vida e a atribuição do Prémio Nobel da Química de 1918 pela síntese do amoníaco, em 1920 (neste ano foram anunciados os Prémios Nobel de 1914 a 1919), foi controversa por essa razão. Os franceses, belgas e britânicos indignaram-se com a atribuição pois a justificação para o Prémio tinha por base a importância da síntese do amoníaco para a agricultura, encobrindo a sua relevância para a indústria dos explosivos e o papel activo de Haber na I Guerra Mundial. Alguns laureados recusaram os prémios e um deles não compareceu à cerimónia 


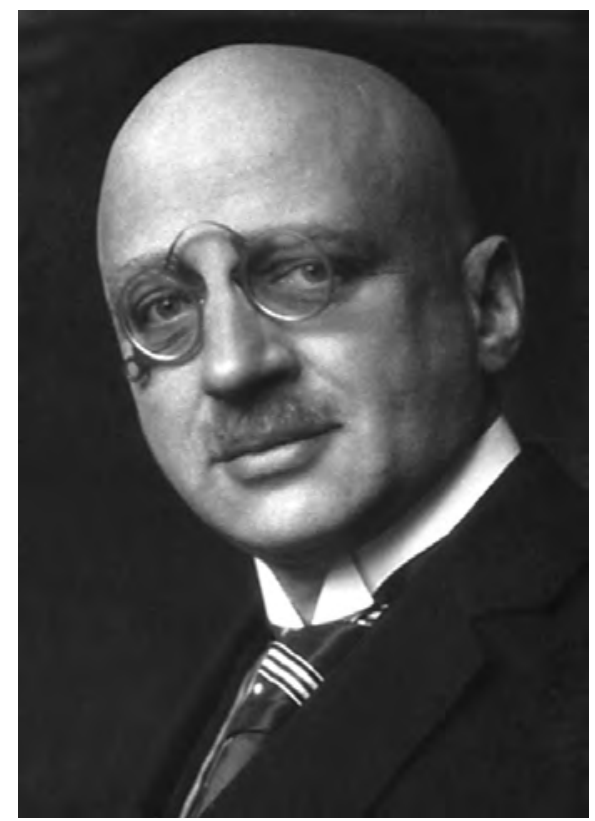

Figura 9 - Haber, por alturas da atribuição do Prémio Nobel [9]

de atribuição. A palestra de Haber na cerimónia (Figura 9) foi totalmente omissa na questão da "pólvora a partir do ar” tendo-se falado apenas do lado virtuoso da síntese do amoníaco [8].

Entre 1920-1926, Haber continuou ainda a colocar o patriotismo ao serviço do seu país tendo embarcado na febre do ouro, trabalhando num projecto patriótico para extrair ouro da água do mar. A hiperinflação que atingiu a Alemanha depois do armistício e a necessidade de pagamento das reparações de guerra aos países vencedores assim o exigiam. No entanto, o projecto teve de ser abandonado pois verificou-se que a concentração de ouro no mar era demasiado baixa para que a sua extracção fosse rentável. No mesmo período, e devido à inflação, Haber haveria de perder grande parte da sua fortuna.

\section{REsignação}

Fritz Haber não era, por natureza, um homem reflectivo. Preferia olhar em frente, resolver problemas, ser pró-activo. No entanto, os acontecimentos dos últimos anos e o avançar da idade tornaram-no mais introspectivo. O pai havia falecido em 1920, o que o marcou. Aos amigos confessava as suas angústias e fraquezas e falava-lhes dos seus recorrentes problemas de saúde (nomeadamente insónias e cardíacos) que o obrigavam a fazer exames de todos os tipos. Sentia-se com poucas forças para a escrita científica. O período 1926-1933 foi, assim, uma espécie de Outono do Patriarca. Dentro do seu instituto Haber vagueava pelos corredores monitorizando o trabalho dos jovens investigadores que havia contratado. Deu-lhes liberdade científica alargada para criar uma atmosfera de pensamento científico livre e empreendedor. Apesar dos problemas de saúde, não parou de fundar novas instituições e procurar financiamento para as antigas. Além das suas funções na Kaiser Wilhelm Society e na Academia de Ciências da Prússia, Haber ajudou a criar o Comité de Emergência para a Ciência Alemã que recrutava financiamento através da indústria privada e de fundos governamentais. Liderou também os esforços para curar as feridas do tempo da guerra que levaram à divisão da ciência europeia, facilitando o retorno da Alemanha ao International Research Council e à IUPAC (International Union of Pure and Applied Chemistry). Em matéria de amores, o segundo casamento de Haber haveria de terminar em 1927, após dez anos de uma relação algo conflituosa.

Entretanto, tinha chegado a Grande Depressão. O comércio mundial caiu 60\% em quatro anos (1929-1932), causando forte impacto nos países industrializados onde o desemprego em massa haveria de provocar fome e desespero [10]. Na Alemanha, a chamada República de Weimar, estabelecida na Alemanha após a I Guerra Mundial, em 1919, tenta a todo o custo relançar a economia, entretanto já depauperada nos anos da década de 1920 em virtude da necessidade de pagamento das reparações de guerra às potências vitoriosas, aliada à hiperinflação e ao grande aumento da dívida externa do país. A política de ajustamento (eufemismo para cortes em despesas sociais) seguida não teve o efeito desejado e, quando a recessão chegou ao seu auge em 1932, a República de Weimar perdera toda sua credibilidade junto da população alemã. Os efeitos na opinião pública da política seguida tiveram como consequência o aumento do sentimento nacionalista, alimentado pela questão do pagamento das reparações de guerra e também pela inclusão, no tratado de paz de Versalhes, da chamada cláusula da “culpa da guerra”, fazendo da Alemanha a única responsável pela mesma. Durante este período foi, assim, inevitável assistir-se à ascensão dos partidos políticos extremistas, com o partido nazi de Adolf Hitler à cabeça e que haveria de chegar ao poder a 30 de Janeiro de 1933. A 23 de Março do mesmo ano, a democracia capitulou quando o parlamento entregou todo o poder ao grande ditador. As perseguições aos judeus já tinham começado. Não demorou muito tempo para Haber perceber que poderia tornar-se um alvo da repressão dos nacional-socialistas. A conversão ao cristianismo décadas antes seria irrelevante; o que contaria seria a sua origem judaica. Menos de uma semana depois, os pressentimentos de Haber tornaram-se realidade. Como director de um instituto, Haber seria obrigado a implementar a "Lei para a Restauração do Serviço Civil Profissional” de Hitler, de 7 de Abril de 1933, e despedir todos os seus colegas de trabalho judeus. Exceptuavam-se aqueles que tinham sido soldados na I Guerra Mundial. Haber, como veterano da guerra, poderia ter ficado na direcção do instituto. Ponderou aceitar a benesse mas depressa teve consciência que a sua situação seria intolerável. A 30 de Abril entregou a sua carta de resignação e, em protesto pela política nazi, declarou firmemente que as considerações raciais eram incompatíveis com a sua visão sobre os deveres académicos. A renúncia de Haber ao cargo não teve, contudo, efeitos imediatos. Deu a si mesmo e aos seus empregadores cinco meses, até 1 de Outubro de 1933, para se encontrar um sucessor.

\section{Epílogo}

O resto da vida de Haber transformou-se na crónica de uma morte anunciada. Foi acumulando perdas-financei- 
ras, físicas e espirituais: a sua casa, o seu instituto, a sua fortuna, as suas forças, fé e identidade. Quando tudo se desmorona, sente-se traído pela nação que tanto tinha ajudado. Durante os cinco meses que ainda esteve no instituto ajudou a colocar alguns jovens cientistas judeus noutras instituições fora da Alemanha. Quanto ao seu futuro, Haber sentia-se incapaz de tomar qualquer decisão. Pretendia sair da Alemanha mas sentia-se demasiado ligado ao país. Estava fraco demais para trabalhar a tempo inteiro mas não podia imaginar-se aposentado. Durante o Verão de 1933, Haber haveria de viajar pela Europa à procura de uma instituição científica que pudesse oferecer-lhe um cargo honorário. Não encontrou nenhuma. Entretanto, recebeu dois convites: um de Chaim Weizmann (futuro primeiro presidente de Israel) para emigrar para a Palestina e ajudar a estabelecer instituições científicas no território; o outro de Sir William Pope para uma posição na Universidade de Cambridge. Haber acaba por decidir aceitar o segundo. Em Cambridge encontrou alguns colegas europeus, muitos dos quais haviam criticado o seu envolvimento na guerra química, o mais proeminente dos quais Ernest Rutherford. No entanto, o rigoroso Inverno inglês de 1933-1934 teve um efeito severo sobre a saúde frágil de Haber. Pediu ao seu médico, Dr. Rudolf Stern, que se juntasse a ele em Basileia para onde seguiria para um sanatório em Locarno, na Suíça. Não chegaria a frequentá-lo. O seu coração traiu-o a 29 de Janeiro de 1934, vindo a falecer num hotel em Basileia na presença do seu médico pessoal. De acordo com a sua vontade, as cinzas da sua primeira mulher, Clara, foram enterradas ao lado dele. No entanto, não em Dahlem, como era da sua vontade, mas em Basileia. Não há nenhum epitáfio inscrito na sua lápide (Figura 10). Pouco tempo antes de falecer terá dito a Chaim Weizmann que tinha tido o

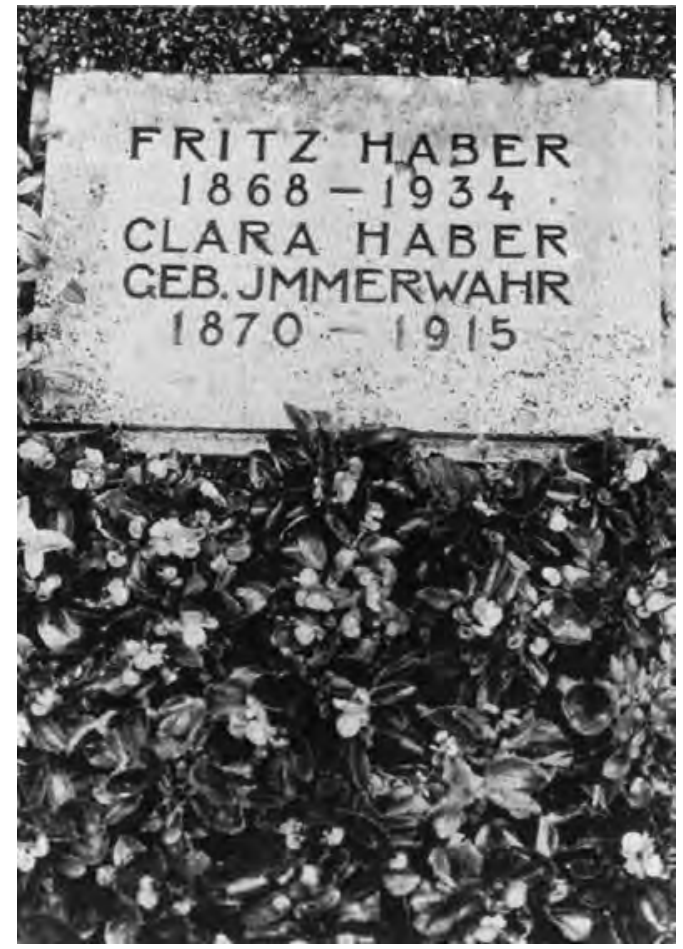

Figura 10 - Campa de Haber e Clara em Hörnli, Basileia, Suiça [3] mundo a seus pés: "Eu era um dos mais poderosos homens da Alemanha. Fui mais do que um grande comandante do exército, mais do que um capitão de indústria. Fui o fundador das indústrias; o meu trabalho era essencial para a expansão económica e militar da Alemanha. Todas as portas estavam abertas para mim." [1]. Einstein haveria de dizer, contudo, que Haber "foi forçado a experimentar toda a amargura de ser abandonado pelas pessoas do seu círculo, um círculo que se importava muito com ele, mesmo reconhecendo os seus dúbios actos de violência. Foi a tragédia do judeu alemão: a tragédia de um amor não correspondido.” [1]. Um ano antes da sua morte, quando Hitler chegou ao poder, Haber escrevera ao amigo Richard Willstätter: "Combato com menos forças os meus quatro inimigos: a insónia, as reivindicações financeiras da minha ex-mulher, a preocupação com o futuro e a sensação de que cometi erros graves na vida." [1]. Haber nunca chegou a dizer que erros tinham sido.

\section{AgRADECIMENTOS}

Gostaria de agradecer à Cristina Rodrigues e à Cristina Galacho a amabilidade que tiveram em contribuir para a melhoria deste artigo.

\section{REFERÊNCIAS}

[1] D. Charles, "Master Mind. The Rise and Fall of Fritz Haber, the Nobel Laureate Who Launched the Age of Chemical Warfare”, HarperCollins e-Books, 2005

[2] V. Smil, "Enriching the Earth: Fritz Haber, Carl Bosch, and the Transformation of World Food Production”, The MIT Press, Massachusetts, USA, 2001

[3] https://www.fhi-berlin.mpg.de/history/Friedrich_HaberArticle.pdf (Fritz-Haber-Institut der Max-Planck-Gesellschaft, acedido a 10-10-2014)

[4] http://minerals.usgs.gov/minerals/pubs/commodity/nitrogen/mcs-2014-nitro.pdf (U.S. Geological Survey, Mineral Commodity Summaries, February 2014, acedido a 10-102014)

[5] J. Calado, "Limites da Ciência”, Fundação Francisco Manuel dos Santos, Lisboa, 2014

[6] "Chemical Warfare Agents Chemistry, Pharmacology, Toxicology, and Therapeutics”, J.A. Romano Jr., B.J. Lukey, H. Salem (Eds.), CRC Press, 2008

[7] L. Haber, "The Poisonous Cloud: Chemical Warfare in the First World War”, Oxford University Press, Oxford, 1986

[8] http://www.nobelprize.org/nobel_prizes/chemistry/laureates/1918/haber-lecture.html (The Official Web Site of the Nobel Prize, acedido a 10-10-2014)

[9] http://www.nobelprize.org/nobel_prizes/chemistry/laureates/1918/haber-bio.html (The Official Web Site of the Nobel Prize, acedido a 10-10-2014)

[10] E. Hobsbawm, “A Era dos Extremos”, Editorial Presença, 2002 


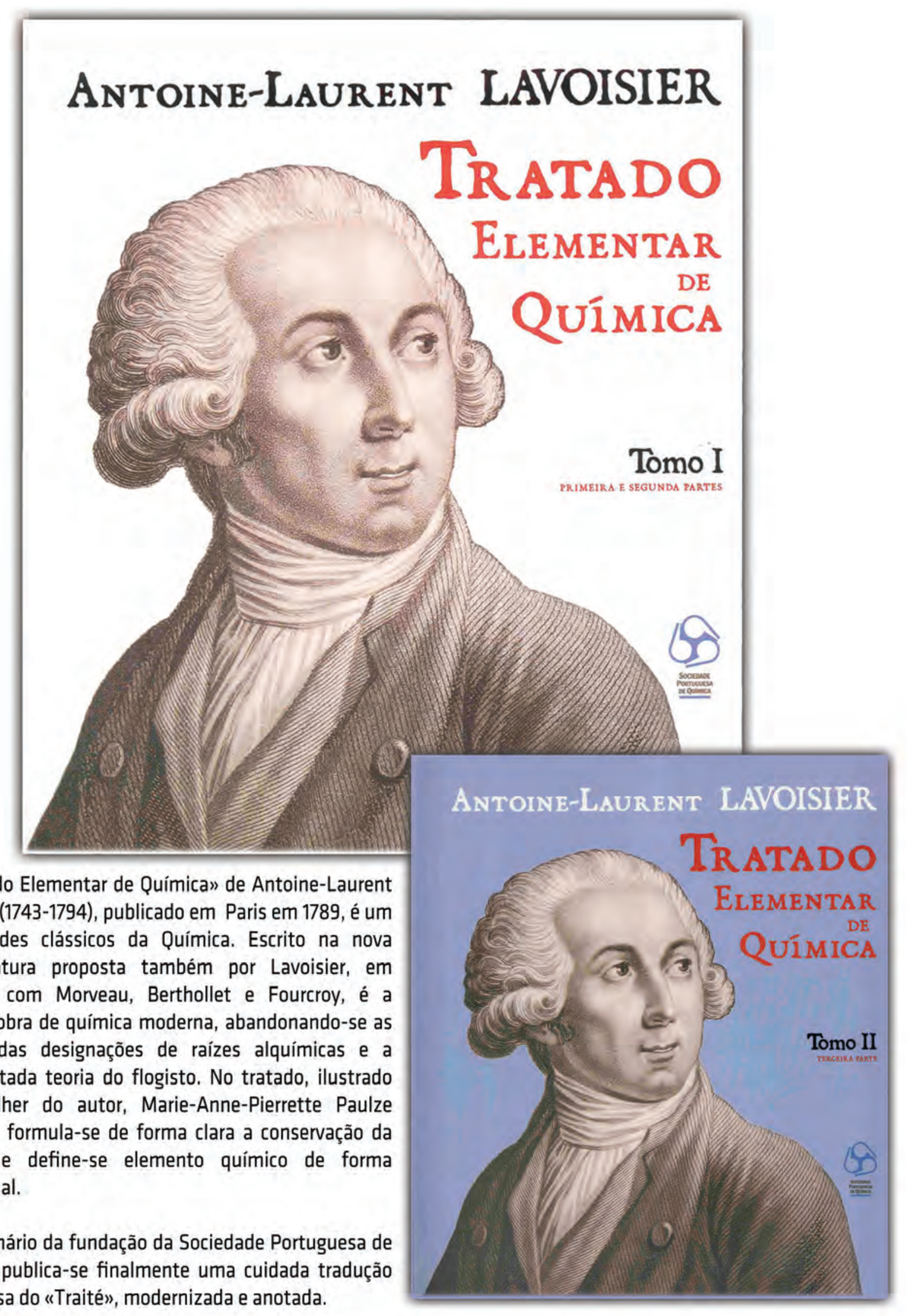

0 "Tratado Elementar de Química» de Antoine-Laurent Lavoisier (1743-1794), publicado em Paris em 1789, é um dos grandes clássicos da Química. Escrito na nova nomenclatura proposta também por Lavoisier, em conjunto com Morveau, Berthollet e Fourcroy, é a primeira obra de química moderna, abandonando-se as inadequadas designações de raízes alquímicas e a desacreditada teoria do flogisto. No tratado, ilustrado pela mulher do autor, Marie-Anne-Pierrette Paulze Lavoisier, formula-se de forma clara a conservação da matéria e define-se elemento químico de forma operacional.

No centenário da fundação da Sociedade Portuguesa de Química, publica-se finalmente uma cuidada tradução portuguesa do «Traité», modernizada e anotada. 